\title{
STUDY OF POTENTIAL DRUG INTERACTIONS AMONG EIGHT MAJOR DEPARTMENTS- GENERAL MEDICINE, ORTHOPEDICS, GYNECOLOGY, PULMONOLOGY, GENERAL SURGERY, PSYCHIATRY, OTOLARYNGOLOGY AND DERMATOLOGY OF A TERTIARY CARE TEACHING HOSPITAL IN SOUTHERN INDIA
}

\author{
TALHA JABEEN ${ }^{*}$, MOHD ABDUL KHADER ${ }^{1}$, A. V. KISHORE BABU ${ }^{2}$, A. SRINIVASA RAO ${ }^{3}$
}

${ }^{1}$ Pharm. D, Department of Pharmacy Practice, Bhaskar Pharmacy College, Moinabad, Hyderabad, Telangana, India, ${ }^{2}$ Assistant Professor, Department of Pharmacy Practice, Bhaskar Pharmacy College, Moinabad, Hyderabad, Telangana, India, ${ }^{3}$ Department of Pharmacology, Bhaskar Pharmacy College, Moinabad, Hyderabad, Telangana, India Email: talhajabeen9191@gmail.com

Received: 01 Apr 2020, Revised and Accepted: 02 May 2020

\section{ABSTRACT}

Objective: To identify frequency, type, severity and predictors of potential drug-drug interactions(pDDIs), potential drug-food interactions(pDFIs), potential drug-alcohol interactions(pDAIs) and potential drug-tobacco interactions(pDTIs) and most frequently interacting drug combination pairs in hospitalized patients from departments(depts) of General Medicine(GM), Orthopedic(Ortho), Gynecology(OBG), Pulmonology(Pulmo), General Surgery (GS), Psychiatry (Psych), Otolaryngology(ENT) and Dermatology (Derm) of study population.

Methods: A Prospective Observational Study was conducted in eight major dept's of a tertiary care teaching hospital for a period of 6 mo. A sample size of 650 prescriptions reflecting admission no's for each department were used.

Results: A total of 650 patients were included in the study. Among them, 282(43.4\%) were males and 368(56.6\%) were females. The mean age of the study population was $39.67 \pm 15.23$. A total of 487 pDDIs, 734 pDFIs, 586 pDAIs and 159 pDTIs were found out of 650 hospitalized episodes. OBG showed the highest pDDIs and pDAIs. Highest pDFIs and pDTIs were seen in Pulmo. The majority of DDIs were minor, DFIs and DAIs were moderate and DTIs were of major in severity. Pharmacokinetic types of interactions were seen in the majority of the depts. Logistic regression analysis showed that Polypharmacy was associated with the occurrence of DIs. Most of the DIs repeated several times in particular depts and a list of these combinations was prepared.

Conclusion: With the high occurrence of overall DIs and characteristic patterns of DIs combination pairs among different departments of the hospital, the presence of clinical pharmacists in hospitals can play a great role, especially in developing nations like India where their role in hospitalized settings is always controversial.

Keywords: Drug interactions, Drug-drug interactions, Drug-food interactions, Drug-alcohol interactions, Drug-tobacco interactions, Departments, Drug combination pairs, Clinical Pharmacist

(C) 2020 The Authors. Published by Innovare Academic Sciences Pvt Ltd. This is an open access article under the CC BY license (http://creativecommons.org/licenses/by/4.0/) DOI: http://dx.doi.org/10.22159/ijpps.2020v12i6.37704. Journal homepage: https://innovareacademics.in/journals/index.php/ijpps

\section{INTRODUCTION}

Drug interactions(DIs) are one of the most common causes of adverse drug reactions and continues to be a public health challenge in both developed and developing countries in the world. These DIs can be defined as an alteration in the efficacy or toxicity of a drug caused by concomitant administration with other drugs, food beverages, and other supplements [1]. With thousands of drugs available worldwide and a substantial increase in drug discovery processes, the range of possibilities for drug interactions is considerable. It is reported that elderly patients with their increased complexity of the disease and therapeutic regimen are more susceptible to the occurrence of DIs [2].

However, these DIs may also occur independently in patients of all age groups. As the pattern of medications received by patients of different age groups and in different departments in a hospital is more complex, it is not easy to estimate the occurrence of DIs accurately. The prescriptions having 3 or more drugs had increased from $11.8 \%$ in $1988-1994$ to $20.08 \%$ in $2007-2010$ and having 5 or more drugs have increased from $4 \%$ to $15.01 \%$ during the same time period in the United States $[3,4]$.

The mechanism implicated in the occurrences of DIs can be Pharmacokinetic (PK) with alteration in the absorption, distribution, metabolism, and excretion of object drug or Pharmacodynamic (PD) in which interaction is close to the target organ and has an additive or antagonistic effect on the pharmacological action of the object drug [5].
About $30 \%$ of all adverse drug events increasing the hospital stay and healthcare cost of patients are related to DIs [6, 7].

Therefore, reviewing the therapy by the clinical pharmacist based on the physiological conditions of the patient and considering the type of allergies, medication history, and social habits of the patient, the clinical pharmacist may play a key role in preventing different types of DIs and adverse events.

Not much data is available on the distribution pattern of DIs in different department's (dept's) of the hospital. There are several published data regarding the pattern of DIs in a particular department of the hospital or the overall interactions found in particular age groups $[2,8]$. Further, the literature has mainly focused on drug-drug interactions (DDIs), while there are also risks of occurrence of DIs with food, alcohol, and tobacco [9-11]. There are some very well-known potential drug-food interactions that are potentially dangerous and may result in therapeutic failure. With an increasing population taking alcohol and tobacco, many drugs interact adversely with them. Hence this study aims to find out the frequency, type, severity, and predictors of potential drug-drug interactions (pDDIs), potential drug-food interactions (pDFIs), potential drug-alcohol interactions (pDAIs) and potential drug-tobacco interactions (pDTIs) and the most frequently interacting drug combination pairs in hospitalized patients from departments (depts) of General medicine (GM), Orthopedic (Ortho), Pulmonology (Pulmo), General Surgery (GS), Psychiatry (Psych), Otolaryngology (ENT) and Dermatology (Derm) of the study population, which will help the doctor to be aware of these 
interactions when prescribing and a pharmacist working in clinical settings to gain a well-grounded knowledge in the prevention, detection, and management of these interactions and contribute greatly to the patient's safety and wellbeing.

Table 1: Demographic profile of the patients from different departments of the hospital

\begin{tabular}{|c|c|c|c|}
\hline S. No. & Parameters & Total no & $\%$ \\
\hline \multirow[t]{24}{*}{1} & $\begin{array}{l}\text { Gender wise distribution } \\
\text { General Medicine }\end{array}$ & & \\
\hline & -Male & 55 & $55 \%$ \\
\hline & -Female & 45 & $45 \%$ \\
\hline & Orthopedic & & \\
\hline & -Male & 45 & $45 \%$ \\
\hline & -Female & 55 & $55 \%$ \\
\hline & Gynecology & & \\
\hline & -Male & 0 & $0 \%$ \\
\hline & -Female & 100 & $100 \%$ \\
\hline & Surgery & & \\
\hline & -Male & 50 & $50 \%$ \\
\hline & -Female & 50 & $50 \%$ \\
\hline & Otolaryngology & & \\
\hline & -Male & 39 & $39 \%$ \\
\hline & -Female & 61 & $61 \%$ \\
\hline & Pulmonology & & \\
\hline & -Male & 35 & $70 \%$ \\
\hline & -Female & 15 & $30 \%$ \\
\hline & Psychiatry & & \\
\hline & -Male & 33 & $66 \%$ \\
\hline & -Female & 17 & $34 \%$ \\
\hline & Dermatology & & \\
\hline & -Male & 25 & $50 \%$ \\
\hline & -Female & 25 & $50 \%$ \\
\hline \multirow[t]{33}{*}{2} & Age wise distribution & & \\
\hline & General Medicine & & \\
\hline & 18-30years & 28 & $28 \%$ \\
\hline & 31-60years & 60 & $60 \%$ \\
\hline & $>60$ years & 12 & $12 \%$ \\
\hline & Orthopedic & & \\
\hline & 18-30years & 24 & $24 \%$ \\
\hline & 31-60years & 71 & $71 \%$ \\
\hline & $>60$ years & 5 & $5 \%$ \\
\hline & Gynecology & & \\
\hline & 18-30years & 58 & $58 \%$ \\
\hline & 31-60years & 42 & $42 \%$ \\
\hline & $>60$ years & 0 & $0 \%$ \\
\hline & Surgery & & \\
\hline & 18-30years & 21 & $21 \%$ \\
\hline & 31-60years & 68 & $68 \%$ \\
\hline & >60years & 11 & $11 \%$ \\
\hline & Otolaryngology & & \\
\hline & 18-30years & 30 & $30 \%$ \\
\hline & 31-60years & 60 & $60 \%$ \\
\hline & $>60$ years & 10 & $10 \%$ \\
\hline & Pulmonology & & \\
\hline & 18-30years & 10 & $20 \%$ \\
\hline & 31-60years & 28 & $56 \%$ \\
\hline & $>60$ years & 12 & $24 \%$ \\
\hline & Psychiatry & & \\
\hline & 18-30years & 12 & $24 \%$ \\
\hline & 31-60years & 33 & $66 \%$ \\
\hline & $>60$ years & 5 & $10 \%$ \\
\hline & Dermatology & & \\
\hline & 18-30years & 29 & $58 \%$ \\
\hline & 31-60years & 19 & $38 \%$ \\
\hline & $>60$ years & 2 & $4 \%$ \\
\hline
\end{tabular}

\section{MATERIALS AND METHODS}

\section{Methodology}

The research was conducted in a tertiary teaching hospital, Bhaskar General Hospital, for a period of 6 mo (i.e. June 2019-November 2019) in GM, OBG, Ortho, GS, Pulmo, ENT, Psych, and Derm depts.

\section{Type of study}

Prospective Observational Study.

\section{Study design}

The data was collected from the patient's medical record or medical profile sheet for a duration of 6 mo from 8 different departments in a tertiary care hospital. The data collected from the patient's medical record included demographic details of patient, chief complaint, history of present illness, lab investigations, past medical conditions, medical or any potential allergic history, final diagnosis, day-wise medication therapy with their dose, frequency, route, duration of therapy and dosage-form. 
Consent was obtained from all subjects before the study. All data were collected and analyzed for this study.

Inclusion criteria were patients of both gender aged more than $18 \mathrm{y}$ with complete clear data and exclusion criteria were patients with less than $18 \mathrm{y}$ old and prescription with uncleared data.

A total of 650 prescriptions with 100 prescriptions each were from GM, Ortho, OBG, GS, and ENT, and 50 each from Psych, Pulmo, and Derm depts reflecting admission numbers for each dept were assessed for pDIs.

As the minimum sample size recommended by the W. H. O. is 600 , the current sample size was considered as an appropriate sample size for this study.

\section{Study measures}

pDDIs, pDFIs, pDAIs, and pDTIs were detected using the drug interaction checking software tool Micromedex ${ }^{\circledR}-2.7$ and www.drugs.com database.
For categorical variables, frequency/percentages were calculated, and continuous variables were expressed as mean \pm SD. The binary logistic regression model was used to analyze the association of occurrence of pDIs with specified risk factors, including gender, age, and the number of drugs prescribed. $\mathrm{P}<0.05$ and $\mathrm{P}<0.01$ were considered statistically significant and highly significant, respectively. All statistical analyses were done using the SPSS software database. Bar diagrams, tables, and charts were created using Microsoft Excel 2010 version to depict percentages and averages.

\section{RESULTS}

A total of 650 patients from eight different departments of the hospital were included in the study. Among them, 282 (43.38\%) were males and 368 (56.61\%) were females. The demographic profile of the patients is shown in table 1 . The mean age of the study population was $39.67 \pm 15.23$. The mean number of medications received per prescription in each dept is shown in fig. 1.

The mean no of potential DIs per prescription in each dept is shown fig. 2.

\section{Statistical analysis}

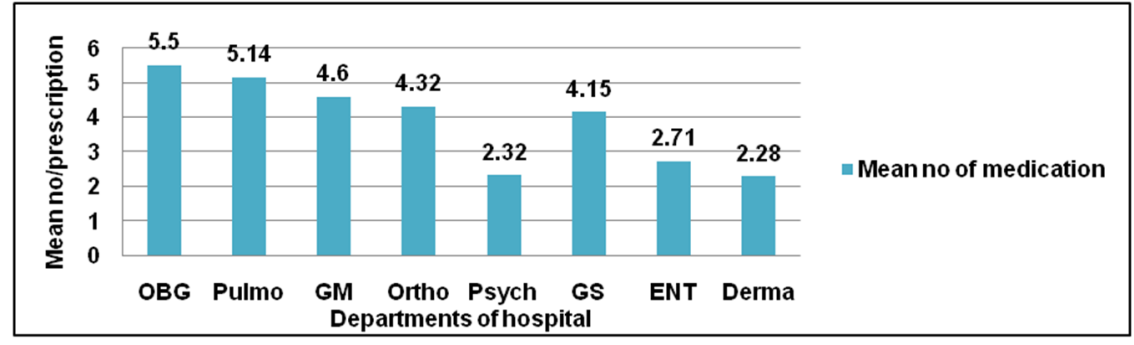

Fig. 1: Mean no of medication per prescription in each department

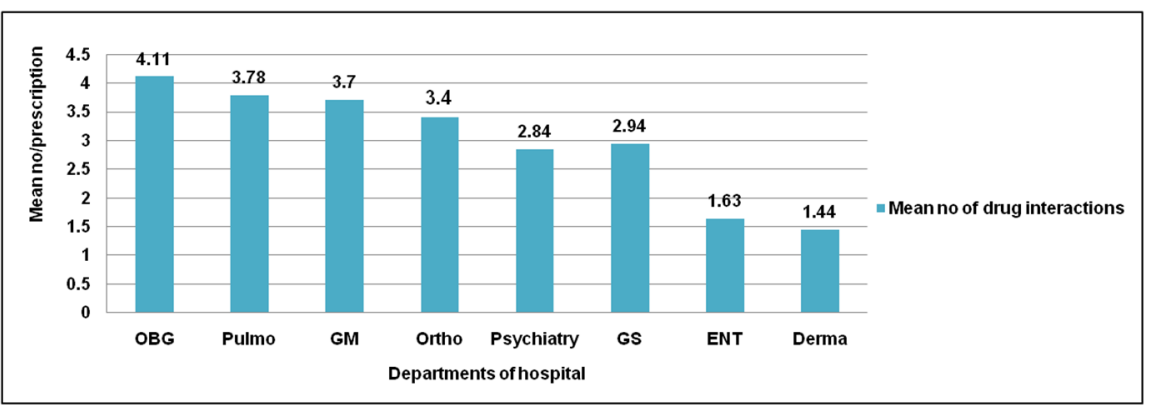

Fig. 2: Mean no of DIs per prescription in different departments of hospital

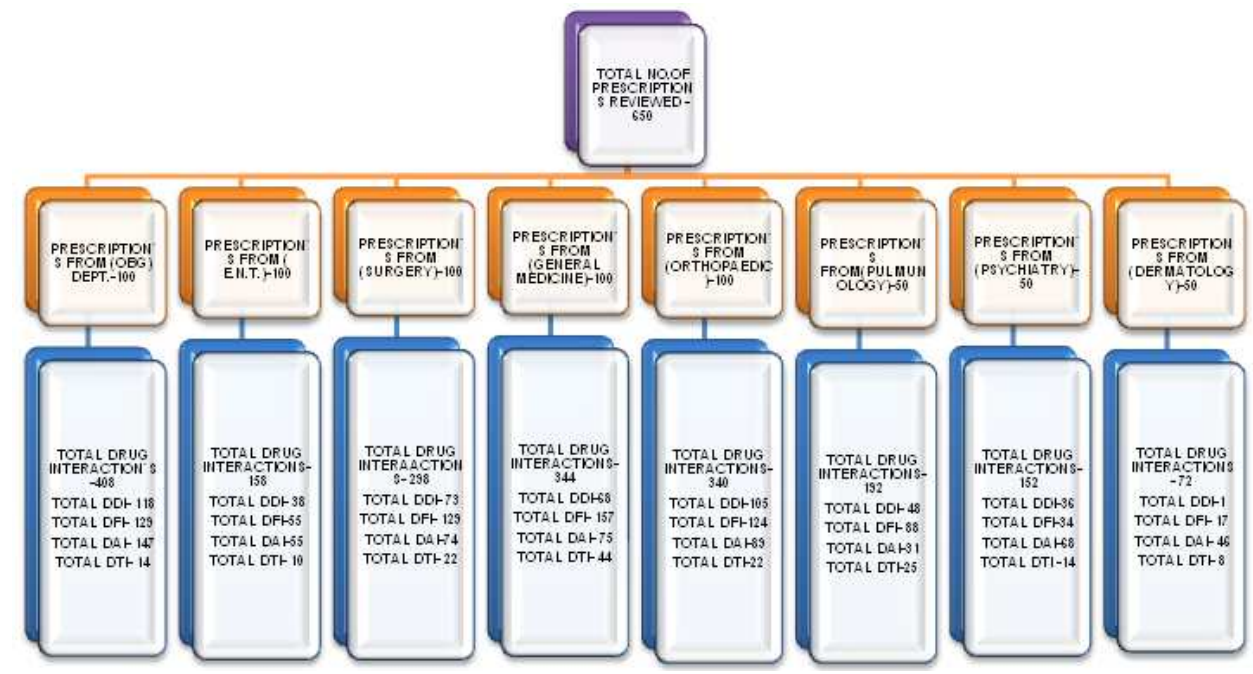

Fig. 3: An outline of the whole study 
A total of 487 pDDIs, 734 pDFIs, 586 pDAIs and 159 pDTIs were seen in 650 prescriptions from GM, OBG, Ortho, ENT, GS, Psych, Pulmo and Derm depts of a tertiary care teaching hospital. Fig. 3 provided an outline of the whole study.
The fig. 4 demonstrates the occurrence of pDDIs, pDFIs, pDAIs and pDTIs among different depts of hospital. The OBG and Pulmo dept has significantly higher DIs when compared to the other 6 depts. The Derm and ENT depts have the least number of DIs.

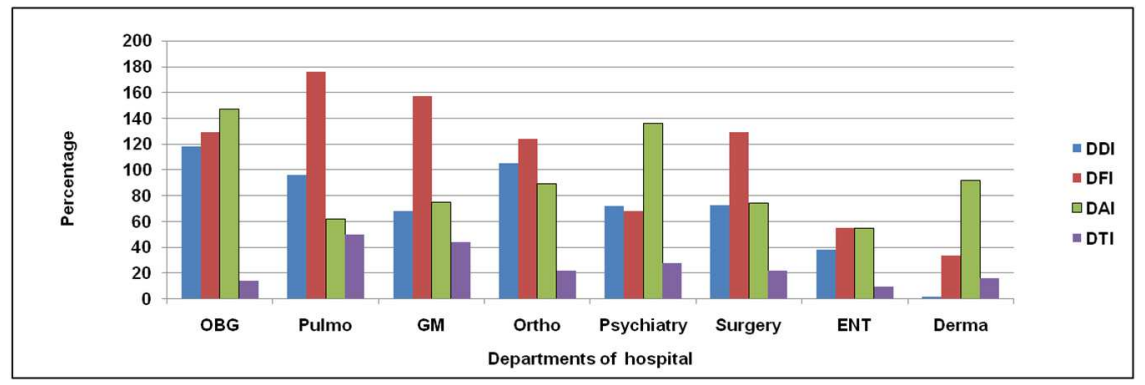

Fig. 4: Comparison of DIs in different departments of hospital

DDIs among different depts were the majority of moderate and minor types (fig. 5).
Except psychiatry, moderate type of DFI were predominantly seen in all depts (fig. 6).

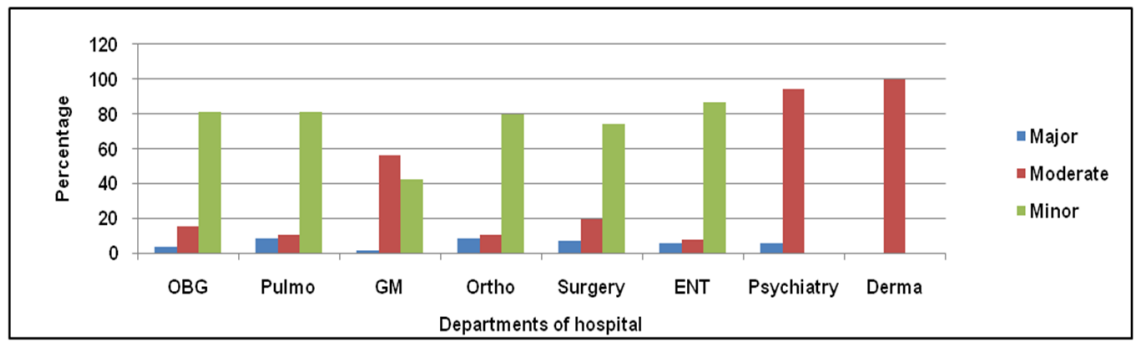

Fig. 5: Severity of DDI in different departments of hospital

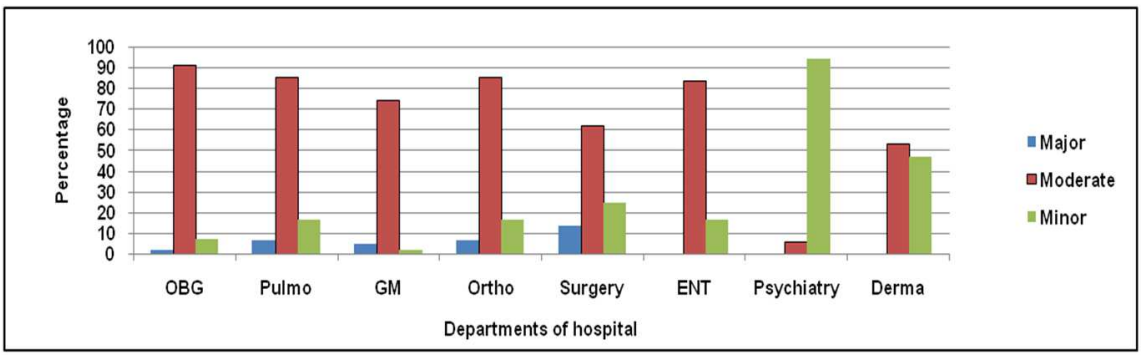

Fig. 6: Severity of DFI in different departments of hospital

The severity of DAI also followed a similar trend with moderate type predominating in all depts except medicine and surgery where major DAI are of a major type. Many contraindicated types of interactions have also been identified in various depts (fig. 7).

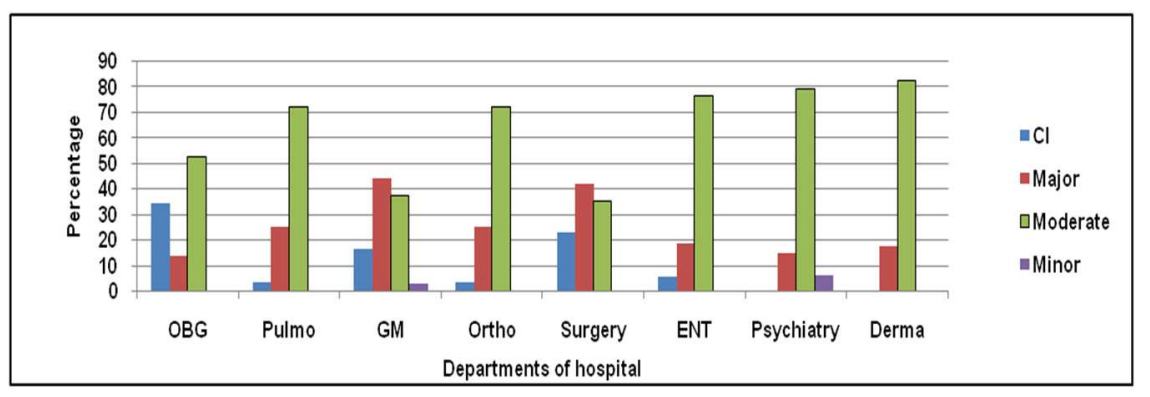

Fig. 7: Severity of DAI in different departments of hospital 
All the depts had the majority of major type of DTI (fig. 8).

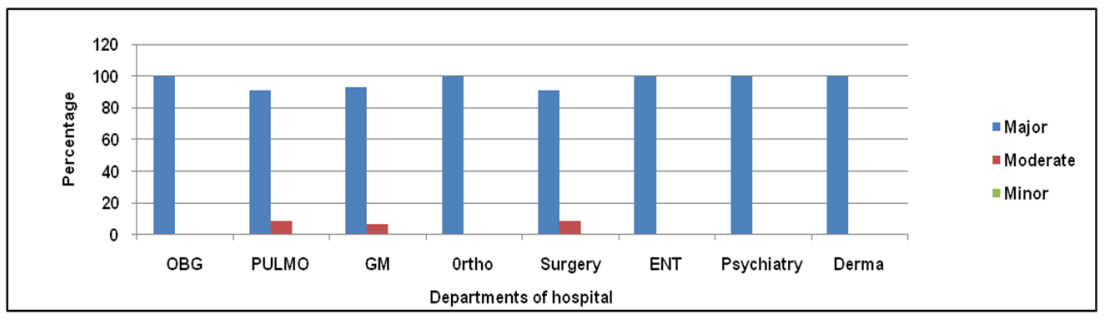

Fig. 8: Severity of DTI in different departments of hospital

No significant difference among males and females with regard to severity of DIs were observed.
The majority of DIs in different depts. of hospitals were PK in nature, except for the variations in dermatology and psychiatry (fig. 9).

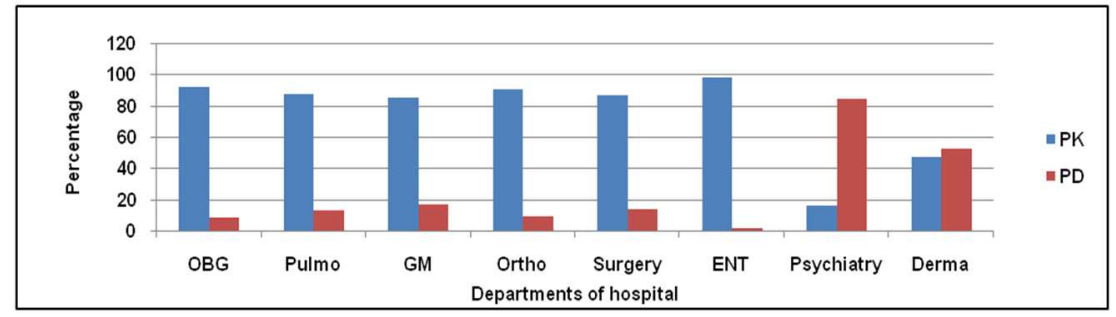

Fig. 9: Distribution of PK and PD interactions in different departments of hospital

Logistic regression analysis showed a significant correlation with regard to the mean number of medications per prescription and mean no of potential DIs among different depts. of the hospital. $(\mathrm{r}=0.88$. $\mathrm{p}=0.003488)$ fig. 10

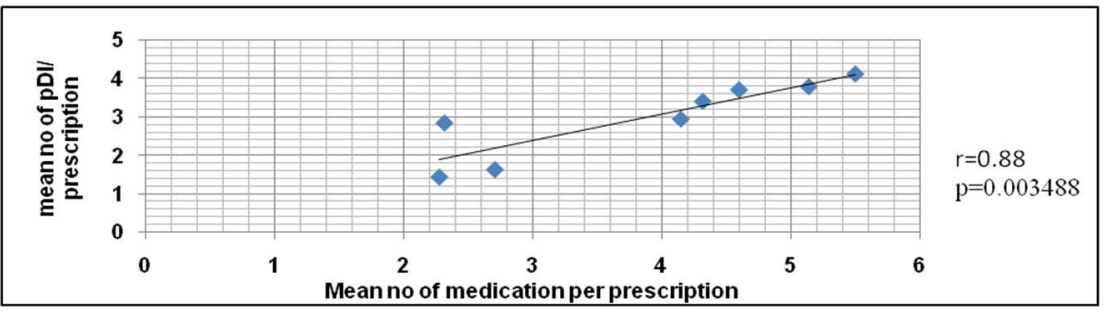

Fig. 10: Relationship between mean no of medications per prescription and mean no of DI per prescription

There were no significant differences with regard to the age of patients and gender with number of DIs seen.
Table 2,3,4, 5 shows the most common DI pairs in all the eight depts of the hospital.

Table 2: Most common DDI pairs in all the eight departments of the hospital

\begin{tabular}{|c|c|c|c|c|}
\hline Department & Drug-drug combination pairs & No. of cases & Severity & Consequences of DDIs \\
\hline $\begin{array}{l}\text { General } \\
\text { medicine }\end{array}$ & $\begin{array}{l}\text { a.)Ceftriaxone+Diclofenac } \\
\text { b.)Atorvastatin+Pantoprazole } \\
\text { c.)Clopidogrel+Pantoprazole }\end{array}$ & $7,4,4$ & $\begin{array}{l}\text { Minor, } \\
\text { Moderate } \\
\text { Moderate }\end{array}$ & $\begin{array}{l}\text { Increase concentrations of diclofenac, } \\
\text { Increase blood levels of atorvastatin, } \\
\text { Decrease effectiveness of clopidogrel }\end{array}$ \\
\hline Orthopedic & $\begin{array}{l}\text { a.)Ceftriaxone+Diclofenac } \\
\text { b.)DIclofenac+Aceclofenac } \\
\text { c.)Methotrexate+Prednisolone }\end{array}$ & $35,6,2$ & $\begin{array}{l}\text { Minor, Major } \\
\text { Moderate }\end{array}$ & $\begin{array}{l}\text { Increase concentration of diclofenac } \\
\text { Increased risk of bleeding, Increased blood } \\
\text { levels of methotrexate }\end{array}$ \\
\hline Gynecology & $\begin{array}{l}\text { a.)Ceftriaxone+Diclofenac } \\
\text { b.)Amikacin+Ceftriaxone } \\
\text { c.)Tramadol+Ondansetron }\end{array}$ & $40,2,2$ & $\begin{array}{l}\text { Minor, } \\
\text { Moderate Major }\end{array}$ & $\begin{array}{l}\text { Increase concentration of diclofenac, } \\
\text { Increases risk of kidney damage. Agitation }\end{array}$ \\
\hline Surgery & $\begin{array}{l}\text { a.)Ceftriaxone+Diclofenac } \\
\text { b.)Amikacin+Ceftriaxone } \\
\text { c.)Aspirin+Clopidogral }\end{array}$ & $28,4,2$ & $\begin{array}{l}\text { Minor Moderate } \\
\text { Moderate }\end{array}$ & $\begin{array}{l}\text { Increase concentration of diclofenac, } \\
\text { Increases risk of kidney damage Increase risk } \\
\text { of bleeding }\end{array}$ \\
\hline Otolaryngology & $\begin{array}{l}\text { a.) Ceftriaxone+Diclofenac } \\
\text { b.) Azithromycin+Moxifloxacin }\end{array}$ & 10,2 & Minor, Major & $\begin{array}{l}\text { Increase concentration of diclofenac, QT } \\
\text { interval prolongation }\end{array}$ \\
\hline Pulmonology & $\begin{array}{l}\text { a.)Azithromycin+Levalbuterol } \\
\text { b.)Theophylline+Budesonide } \\
\text { c.) Levalbuterol+Furosemide }\end{array}$ & $5,4,4$ & $\begin{array}{l}\text { Moderate } \\
\text { Moderate } \\
\text { Moderate }\end{array}$ & $\begin{array}{l}\text { QT interval prolongation, Hypokalaemia and } \\
\text { Increase T levels, Hypokalemia and ECG } \\
\text { changes. }\end{array}$ \\
\hline Psychiatry & $\begin{array}{l}\text { a.) Olanzapine+Valproate } \\
\text { b.)Risperidone+Olanzepine } \\
\text { c.) Clonazepam+Paroxetine }\end{array}$ & $6,6,6$ & $\begin{array}{l}\text { Moderate } \\
\text { Moderate } \\
\text { Moderate }\end{array}$ & $\begin{array}{l}\text { Decrease in olanzapine plasma concentration, } \\
\text { Increase side effects like drowsiness, blurred } \\
\text { vision, Increase side effects like drowsiness, } \\
\text { blurred vision. }\end{array}$ \\
\hline Dermatology & a.) Hydroxyzine+Cetirizine & 1 & Moderate & $\begin{array}{l}\text { Increase side effects like dizziness, } \\
\text { drowsiness }\end{array}$ \\
\hline
\end{tabular}


Table 3: Most common DFI pairs in all the eight departments of the hospital

\begin{tabular}{|c|c|c|c|c|}
\hline Department & Drug-food combination pairs & No. of cases & Severity & Consequences OF DFIs \\
\hline \multirow[t]{3}{*}{ General medicine } & a.)Pantoprazole+Cranberry & 44 & Moderate & Reduced effectiveness of pantoprazole \\
\hline & b.)Acetaminophen + Cabbage/Food & 27 & Moderate, Minor & Decreased acetaminophen effectiveness. \\
\hline & c.)Furosemide+Food & 10 & Moderate & Decreased furosemide efficacy \\
\hline \multirow[t]{2}{*}{ Orthopedic } & a.)Acetaminophen+Cabbage/Food & 18 & Moderate, Minor & Decreased acetaminophen effectiveness. \\
\hline & b.)Cranberry+Ranitidine & 57 & Moderate & Reduced effectiveness of ranitidine. \\
\hline \multirow[t]{2}{*}{ Gynecology } & a.)Cranberry+Ranitidine & 75 & Moderate & Reduced effectiveness of ranitidine. \\
\hline & b.)Food+Ampicillin & 15 & Moderate & Decreased ampicillin concentrations \\
\hline \multirow[t]{3}{*}{ Surgery } & a.)Cranberry+Pantoprazole & 51 & Moderate & Reduced effectiveness of pantoprazole. \\
\hline & b.)Cranberry+Ranitidine & 22 & Moderate & Reduced effectiveness of ranitidine. \\
\hline & c.)Grapefruit+Tramadol & 16 & Major & Increased tramadol plasma concentration \\
\hline \multirow[t]{2}{*}{ Otolaryngology } & a.)Cranberry+Ranitidine & 25 & Minor & Decreased effectiveness of ranitidine \\
\hline & b.)Acetaminophen+Cabbage/Food & 10 & Moderate, Minor & Decreased effectiveness of acetaminophen. \\
\hline \multirow[t]{3}{*}{ Pulmonology } & a.)Acetaminophen+Cabbage/Food & 21 & Moderate, Minor & Decrease effectiveness of acetaminophen. \\
\hline & b.)Theophylline+Caffeine & 12 & Moderate & Increased theophylline plasma levels. \\
\hline & c.)Theophylline+Food & 12 & Moderate & Altered theophylline concentration \\
\hline \multirow[t]{2}{*}{ Psychiatry } & a.)Chlordiazepoxide+Caffeine & 17 & Minor & Decreased effect of chlordiazepoxide \\
\hline & b.) Clonazepam+Caffeine & 10 & Minor & Decreased effects of clonazepam. \\
\hline Dermatology & a.)Acetaminophen+Cabbage/Food & 8 & Moderate, Minor & Decreased acetaminophen effectiveness. \\
\hline
\end{tabular}

Table 4: Most common DAI pairs in all the eight departments of the hospital

\begin{tabular}{|c|c|c|c|c|}
\hline Department & Drug-alcohol combination pairs & No. of cases & Severity & consequences of DAIs \\
\hline $\begin{array}{l}\text { General } \\
\text { medicine }\end{array}$ & $\begin{array}{l}\text { a.) Acetaminophen+Alcohol } \\
\text { b.) Ranitidine+Alcohol } \\
\text { c.) Metronidazole+Alcohol }\end{array}$ & $27,15,12$ & $\begin{array}{l}\text { Major } \\
\text { Moderate, C. I. }\end{array}$ & $\begin{array}{l}\text { Increased risk of hepatotoxicity, Increased } \\
\text { bioavailability of alcohol, Disulfiram like } \\
\text { reaction }\end{array}$ \\
\hline Orthopedic & $\begin{array}{l}\text { a.) Ranitidine+Alcohol } \\
\text { b.) Acetaminophen+Alcohol }\end{array}$ & 57,18 & $\begin{array}{l}\text { Moderate } \\
\text { Major }\end{array}$ & $\begin{array}{l}\text { Increased bioavailability of alcohol, Increased } \\
\text { risk of hepatotoxicity }\end{array}$ \\
\hline Gynecology & $\begin{array}{l}\text { a.) Metronidazole }+ \text { Alcohol } \\
\text { b.) Ranitidine+Alcohol }\end{array}$ & 50,75 & C. I, Moderate & $\begin{array}{l}\text { Disulfiram like reaction, Increased } \\
\text { bioavailability of alcohol }\end{array}$ \\
\hline Surgery & $\begin{array}{l}\text { a.) Ranitidine+Alcohol } \\
\text { b.) Metronidazole+Alcohol } \\
\text { c.) Tramadol+Alcohol }\end{array}$ & $22,17,16$ & $\begin{array}{l}\text { Moderate, C. I. } \\
\text { Major }\end{array}$ & $\begin{array}{l}\text { Increased bioavailability of alcohol, Disulfiram } \\
\text { like reaction, Increased risk of respiratory } \\
\text { depression }\end{array}$ \\
\hline Otolaryngology & $\begin{array}{l}\text { a.) Acetaminophen+Alcohol } \\
\text { b.) Ranitidine+Alcohol }\end{array}$ & 10,25 & $\begin{array}{l}\text { Major } \\
\text { Moderate }\end{array}$ & $\begin{array}{l}\text { Increased risk of hepatotoxicity, Increased } \\
\text { bioavailability of alcohol }\end{array}$ \\
\hline Pulmonology & $\begin{array}{l}\text { a.) Ranitidine+Alcohol } \\
\text { b.) Acetaminophen+Alcohol }\end{array}$ & 6,21 & $\begin{array}{l}\text { Moderate } \\
\text { Major }\end{array}$ & $\begin{array}{l}\text { Increase bioavailability of alcohol. Increased } \\
\text { risk of hepatotoxicity }\end{array}$ \\
\hline Psychiatry & $\begin{array}{l}\text { a.) Chlordiazepoxide+Alcohol } \\
\text { b.) Olanzapine+Alcohol } \\
\text { c.) Clonazepam+Alcohol }\end{array}$ & $\begin{array}{l}17 \\
12,10\end{array}$ & $\begin{array}{l}\text { Moderate } \\
\text { Moderate } \\
\text { Major }\end{array}$ & $\begin{array}{l}\text { Increased sedation } \\
\text { Excessive C. N. S. depression, Increased } \\
\text { sedation }\end{array}$ \\
\hline Dermatology & a.) Levocetirizine+Alcohol & 36 & Moderate & $\begin{array}{l}\text { Increase nervous system side effects of } \\
\text { levocetirizine }\end{array}$ \\
\hline
\end{tabular}

Table 5: Most common DTI pairs in all the eight departments of the hospital

\begin{tabular}{|c|c|c|c|c|}
\hline Departments & Drug-tobacco combination pairs & $\begin{array}{l}\text { No. of } \\
\text { cases }\end{array}$ & Severity & Consequences of dtis \\
\hline \multirow[t]{2}{*}{ General medicine } & a.) Acetaminophen+Tobacco & 27 & Major & Decreased exposure of CYP1A2 substrates \\
\hline & b.) Ondansetron+Tobacco & 12 & Major & Decreased exposure of CYP1A2 substrates \\
\hline Orthopaedic & a.) Acetaminophen+Tobacco & 18 & Major & Decreased exposure of CYP1A2 substrates \\
\hline \multirow[t]{2}{*}{ Gynecology } & a.) Acetaminophen + Tobacco & 8 & Major & Decreased exposure of CYP1A2 substrates \\
\hline & b.) Ondansetron+Tobacco & 6 & Major & Decreased exposure of CYP1A2 substrates \\
\hline \multirow[t]{2}{*}{ Surgery } & a.) Acetaminophen+Tobacco & 14 & Major & Decreased exposure of CYP1A2 substrates \\
\hline & b.) Ondansetron+Tobacco & 6 & Major & Decreased exposure of CYP1A2 substrates \\
\hline Otolaryngology & a.) Acetaminophen+Tobacco & 10 & Major & Decreased exposure of CYP1A2 substrates \\
\hline \multirow[t]{2}{*}{ Pulmonology } & a.) Acetaminophen+Tobacco & 21 & Major & Decreased exposure of CYP1A2 substrates \\
\hline & b.) Theophylline+Tobacco & 12 & Major & Decreased exposure of CYP1A2 substrates \\
\hline Psychiatry & a.) Olanzapine+Tobacco & 8 & Major & Decreased exposure of CYP1A2 substrate \\
\hline Dermatology & a.) Acetaminophen+Tobacco & 21 & Major & Decreased exposure of CYP1A2 substrates \\
\hline
\end{tabular}

\section{DISCUSSION}

DIs, resulting in adverse drug events present a growing concern in healthcare settings. The patient requirement for multiple drug therapy, types of food intake, alcohol and tobacco habits, and the type of disease the patient is suffering from may result in decreased therapeutic benefit, adverse effect, or patient harm through a phenomenon called "Drug Interaction" [12].
In our sample size of 650 patient's medication profile, in which $282(43.38 \%)$ were males and 368(56.61) were females. An increase in the female patient's proportions could be due to $n=100$ female patients from the gynecology dept. The mean age of the study population was $39.67 \pm 15.23$. There was no statistically significant difference among the mean age of patients in various depts and with respect to gender. Mean no of medication per prescription in different depts of the hospital are given in fig. 1, with the highest number obtained from OBG $(5.5 \pm 1.38)$. These numbers were less 
than the mean number of medications per prescriptions among geriatric patients $(6.53 \pm 1.15)$ as reported by Varsha Shetty, et al. [2].

In our study, a total of 487 pDDIs were found in 650 patient medication profiles, with the highest number of pDDIs from OBG dept followed by Ortho, Pulmo, GS, Psych, GM, ENT and Derm having the least pDDIs. The highest number of pDDIs from OBG is in contrast from the study conducted by Lubinga SJ, et al. [13] which showed the less occurrence of pDDIs in OBG. As rightly stated by Ferracini A, et al. [14] during hospitalization, pregnant and breastfeeding women use a complex pharmacotherapy with many drugs prescribed, and hence their prescriptions are more susceptible to pDDIs. Pulmo, the second-highest contributor for pDDIs were having 48 pDDIs in 50 patients. A total of 29 patients (58\%) in the Pulmo dept were having pDDIs pair contributing to a total of 48 pDDIs. A single prescription with 8 pDDIs and two prescriptions having 6 pDDIs each were identified. The higher occurrence of pDDIs in Ortho and GS is in accordance with the study conducted by Ramya Balaprabha G, et al. [15] with the use of antibiotics, analgesic and polypharmacy having contributed to these significantly higher numbers of pDDIs. In our study, the GM ward was having a moderately significant higher pDDIs. These could be due to variations in the study setting, number, and type of comorbidities as well as by the prescribing culture of the physician. However, the overall interaction rate was significantly higher in these depts. A total of 30 patients had contributed to 38 pDDIs in ENT. Lack of practical data was seen in the analysis of pDDIs in the ENT dept. As stated by Woroń J, et al. [16] concomitant use of drugs at the same time can lead to as high as 55\% cases with DDIs in ENT dept. The least number of pDDIs in Derm dept were in accordance with the study conducted by Ramya Balaprabha G, et al. [15]. Pulmo $(10 \%)$, Ortho $(9 \%)$, and GS $(5 \%)$ were having a higher number of major pDDIs. The majority of DDIs were moderate and minor in severity. The majority of interactions were $\mathrm{PK}$ in nature in accordance with the study conducted by Dais D, et al. [17]. Metabolism types of DDIs were predominant and were associated with the induction and inhibition of drug-metabolizing enzymes.

We noticed that many of the drugs given during the hospital stay of the patient were repeated in the discharge summary chart, which the patient takes at home. Therefore, there is a high possibility of the patient taking medicine with certain food and beverages that may result in adverse consequences.

It was observed that not much importance is given by the physician with regard to DFIs when writing a prescription. These interactions constitute a common hidden problem encountered in clinical practice. pDFIs either decrease the action of drugs or increase the action of drugs or cause adverse effects [9]. We, therefore, aim to evaluate the pDFIs occurring among different departments of hospitals.

A total of 734 pDFIs were found in 650 patient's medical records. The highest occurrence of DFIs was found in Pulmo dept with 88 pDFIs were found in 50 patient's medication chart, was in accordance with the study conducted by Ramalingam $\mathrm{K}$ et al. [16]. The GS, OBG, and Ortho had a significant higher number of pDFIs. Psych dept had moderately high pDFIs, with caffeine being the major reason for causing an additive pharmacodynamic interaction with psychiatric medications. The ENT and Derm had relatively less number of pDFIs.

The majority of pDFIs were of moderate severity $(73.16 \%)$. The study conducted by an Indian author among hospitalized cardiac patients also revealed a maximum number of DFIs were of moderate severity [18]. 92.64\% of DFIs were PK in nature. Every intake of food may have a significant impact on the process of absorption, distribution, metabolism, and elimination relating to the higher occurring of PK DFIs [19].

The use of alcohol is common among both young and adults, males and females. Alcohol consumption in India amounted to about 5.4 billion liters in 2016 and was estimated to reach about 6.5 billion liters by 2020 [20]. These numbers could be much higher for the rest of Asia and other countries globally. Despite this high prevalence, only a few physicians discuss alcohol use with their patients [21].
In our study, a total of 586 pDAIs were found in a total of 650 patient's medical records. The highest number of pDAIs was found in OBG. This is of significant importance since alcohol consumption by pregnant women can have serious adverse effects on both the mother and the fetus. A survey conducted by CADD among 5,000 Indian women aged between $17-80 \mathrm{y}$, revealed an increase in the rate of women drinking alcohol in India which could be due to peer pressure, exposure to a different lifestyle, and increased stress [22]. Therefore, the utmost caution should be given by the physician and pharmacist to the pregnant mother about alcohol-drug interactions that can have potential adverse life-threatening outcomes. The psychiatry department has the $2^{\text {nd }}$ highest pDAIs with 46 (92\%) of patients having at least 1 DAIs. As stated by Cheng C, et al. [23], individuals with mental health disorders are particularly vulnerable because of their psychotropic medications, which are typically taken for extended periods and are known to have PK and PD interactions with alcohol. The least number of pDAIs were found in the ENT dept. A major point to be noted is $34.01 \%, 22.97 \%, 16 \%, 5.45 \%$, and $3.37 \%$ patients in OBG, GS, GM, ENT, and Ortho respectively had pDAIs which are contraindicated. The majority of pDAIs were PK type (70.81\%), this could be explained by the metabolism of alcohol by the alcohol-dehydrogenase enzyme in the liver and CYP450 enzyme's mainly CYP2E1 [21]. Psych and Derm had a higher number of PD type of pDAIs involving an increased risk of ADE or an increased susceptibility to the medication effects.

Cigarette smoking remains highly prevalent in most of the countries. There are approximately 120 million smokers in India. According to WHO, India is home to $12 \%$ of the world's smoker's population [24]. Cigarette smoking induces several cytochrome enzyme's preferably CYP450 enzymes, notably, CYP1A2. Medications metabolized by CYP1A2 will have a shorter duration of action [25].

A total of 159 pDTIs were seen in a total 650 patient's medical profiles. An interesting finding is a total of only 10 pDTIs pair were seen in 650 patient's which had contributed to a total of 159 pDTIs. 98.44\% of pDTIs were of PK in nature. 95.59\% were found to be Major in severity. This impact of cigarette smoking needs to be considered in planning and assessing response to drug therapy.

These interactions are difficult to observe clinically in patients because of shorter hospital stays of patients, incomplete information given by the patient to the doctor or pharmacist and the complexity of PK parameters to assess.

\section{Clinically relevant measures that can be taken to possibly avoid drug interactions}

- Concurrent use of Ceftriaxone and Diclofenac in prescriptions by the physician in many departments was seen. Although the interaction is minor and clinically not observed much, the interaction has exaggerated hemodynamically mediated Acute Renal Failure in a post-surgical patient [26]. Therefore, the patient's on this combination therapy should be monitored for renal functionsparticularly volume-depleted patients, and can be avoided by removing or replacing NSAID with another analgesic or renal sparing NSAIDS (non-selective or coxib's) can be preferred.

- The interaction between Atorvastatin and Pantoprazole can be prevented by replacing Pantoprazole with other PPI like Rabeprazole [27].

- The interaction between Clopidogrel and Pantoprazole can be prevented by replacing Pantoprazole with Ranitidine [27].

- Concurrent use of two NSAIDs at the same time (Diclofenac+Aceclofenac) may increase the risk of side effects reported with this class of drug i.e. stomach ulcer, GI bleeding. This interaction can be prevented by combining NSAID with Acetaminophen for mild to moderate pain [28].

- As Methotrexate and Prednisone is an effective combination for Rheumatoid Arthritis, the increased blood levels of Methotrexate and the adverse effect of this interaction can be prevented by giving low doses of Prednisone [29].

- Concurrent use of Amikacin and Ceftriaxone may result in nephrotoxicity. The patient's renal condition should be monitored particularly in volume-depleted patients and can be avoided by 
replacing Ceftriaxone with an antibiotic that is not dependent on renal clearance or by reducing the dose of Ceftriaxone [30].

- Concurrent use of Aspirin and Clopidogrel may cause unusual bleeding. The monitoring of blood count should be done if coadministration is needed [31].

- Using Moxifloxacin with Azithromycin can increase the risk of an irregular heart rhythm that can be serious and life-threatening. The combination should be avoided and if suspected, immediate ECG monitoring and patient electrolyte condition or patient's previous cardiovascular conditions should be evaluated [32].

- Patients should be advised regarding cabbage and food intake with Acetaminophen [33].

- Caffeine consumption altering the therapeutic response of Psychiatric medication and Theophylline can be prevented by advising the patient to avoid the use of caffeine and caffeinated products when prescription with such drugs are written [34].

- Often, DFIs can be avoided by prescribing the drug an hour before or after meal consumption.

- Education of the patient on the potential risk factors associated with concurrent alcohol, tobacco, and medication use should be done by the Doctor and Clinical Pharmacist.

However, as the development of clinically relevant DIs is reported to be unpredictable and may vary with an individual to individual, we agree with Janchawee B, et al. that DIs often need not always have clinically important adverse consequences but it is important to identify the DIs in order to prevent any harm to the patient's [35].

Relating to the high prevalence of pDDIs, pDFIs, pDAIs, and pDTIs among different depts of the hospital, we recommend that Clinical Pharmacists should be posted in every hospital within India. Furthermore, a Clinical Pharmacist should have the skills and abilities to assess drug therapy, identify and prevent the medications that are having the potential to cause DIs, thereby minimizing the undesirable or adverse outcome in medical care and improving the quality of care given to the patients.

The prescription should be essentially monitored in the respective dept's of the hospital found with which high prevalence rate of DIs. The food-related choice should be advised by the Clinical Pharmacist to the patient at the time of prescription review.

As the teaching hospitals are the role models for the medical students, the prescribing behavior of the teacher can affect the students and can also influence the policymakers by informing them about the quality of drug use in health facilities.

India, being the hub for the majority of the smoker's globally, we, therefore, recommend the studies to be conducted with regard to the prevalence of alcohol and tobacco consumption among patient receiving medication, thereby preventing the DIs in this area and through education to the patient by the Clinical Pharmacist, Physician, and Health care professionals to promote safe and effective therapies.

The pDIs observed in our study warrants the careful use of medications and their strict monitoring to avoid DIs.

\section{LIMITATIONS}

Our study is a medical record-based study and focuses on potential or theoretical DIs without direct interactions with the patient. The non-prescription drugs were not taken into account. Studies based on the prevalence of actual DIs among patients may be more significant providing real-time data.

\section{CONCLUSION}

In a country like India where the role of Clinical Pharmacist in the hospitalized setting is controversial, the large fig. of pDDIs, pDFIs, pDAIs, and pDTIs indicates their essential role in optimization of therapeutic regimen and quality of care provided to the patients. A characteristic pattern of DIs combination pairs were observed among the eight departments of the hospital. Hence these combinations should be corrected. Patient education regarding certain food choices, alcohol, and tobacco usage with medication should be given by the clinical pharmacist at the time of prescription review. The use of electronic systems for assessing DIs should be encouraged. A list of commonly used drug combination pairs found in the particular dept of the hospital can be given to the physician which helps in avoiding these DIs to the maximum and improves the quality of care provided to the patient.

\section{ACKNOWLEDGMENT}

We are grateful to the faculty of Bhaskar Pharmacy College and Bhaskar General Hospital for their assistance and support in doing this research and reviewing the manuscript.

\section{ABBREVIATIONS}

pDDIs-Potential drug-drug Interactions, pDFIs-Potential drug-food Interactions, pDAIs-Potential drug-alcohol Interactions, pDTIsPotential drug-tobacco Interactions, dept-Department, PKPharmacokinetic, DIs-Drug Interactions, ADE-Adverse drug event, OBG-Obstetrics and Gynaecology, GM-General Medicine, OrthoOrthopaedics, Pulmo-Pulmonology, GS-General Surgery, PsychPsychiatry, Derm-Dermatology, E. N. T-Ear, Nose, and Throat, PDI'sPotential Drug interactions, W. H. O-World Health Organisation, SPSS-Statistical Package for the Social Science, ECGElectrocardiography, C. I-Contraindicated, C. N. S--Central Nervous System, CADD-Community Against Drunk Driving, PDPharmacodynamic, No-Number, Cyp 450-Cytochrome p 450, Cyp 2E1-Cytochrome 2E1, NSAID-Non-Steroidal Anti Inflammatory Disease, PPI-Proton pump inhibitors, G. I-Gastrointestinal

\section{FUNDING}

$\mathrm{Nil}$

\section{AUTHORS CONTRIBUTIONS}

This work was carried out in collaboration with all authors. Authors TJ, MAK designed the study, wrote the protocol, managed the analysis of the study, performed the statistical analysis, and managed the literature searches. Author AV KB assisted in writing the draft of the manuscript.

\section{CONFLICT OF INTERESTS}

\section{There is no conflict of interest.}

\section{REFERENCES}

1. Manzi SF, Shannon M. Drug Interactions-a review. Clin Pediatr Emerg Med 2005;6:93-102.

2. Shetty V, Chowta MN, Chowta KN, Shenoy A, Kamath A, Kamath P. Evaluation of potential drug-drug interactions with medications prescribed to geriatric patients in a tertiary care hospital. J Aging Res 2018;3-4:1-6.

3. Charlesworth CJ, Smit E, Lee DSH, Alramadhan F, Odden MC. Polypharmacy among adults aged $65 \mathrm{y}$ and older in the United States: 1988-2010. J Gerontol A Biol Sci Med Sci 2015;70:989-95.

4. Aberathna A, Morrissey H, Ball P, Zawahir S. Antibiotics utilization patterns and direct cost in emergency treatment unit in Sri Lanka. Int J Curr Pharm Res 2019;11:119-22.

5. Greenblatt DJ. Mechanisms and consequences of drug-drug interactions. Clin Pharmacol Drug Dev 2017;6:118-24.

6. Tsui VWL, Thomas D, Tian S, Vaida AJ. Adverse drug events, medication errors, and drug interactions. In: Clinical Pharmacy Education, Practice and Research; 2019. p. 227-45.

7. Setiawan SI, Ascobat P. Adverse reactions to first-line antituberculosis drugs as a risk factor of pulmonary tuberculosis treatment default in jakarta, Indonesia. Int J Appl Pharm 2019;11:80-3.

8. ODJ. Study of drug-drug interactions in the medication charts in medicine wards at a tertiary care hospital, Bangalore. IJOPP 2012;5:61-4.

9. Bushra R, Aslam N, Khan AY. Food-drug interactions. Oman Med J 2011;26:77-83.

10. Johnson BA, Seneviratne C. Alcohol-medical drug interactions. Handb Clin Neurol 2014;125:543-59. 
11. Zevin S, Benowitz NL. Drug interactions with tobacco smoking. An update. Clin Pharmacokinet 1999;36:425-38.

12. Gebretsadik Z, Gebrehans M, Getnet D, Gebrie D, Alema T, Belay YB. Assessment of drug-drug interaction in ayder comprehensive specialized hospital, mekelle, Northern Ethiopia: a retrospective study. Biomed Res Int 2017. https://doi.org/10.1155/2017/9792363.

13. Lubinga SJ, Uwiduhaye E. Potential drug-drug interactions on in-patient medication prescriptions at mbarara regional referral hospital (MRRH) in western uganda: prevalence, clinical importance and associated factors. Afr Health Sci 2011;11:499-507.

14. Ferracini A, Rodrigues A, Visacri M, Stahlschmidt R, Silva N, Surita F, et al. Potential drug interactions and drug risk during pregnancy and breastfeeding: an observational study in a women's health intensive care unit. Rev Bras Ginecol Obstet 2017;39:258-64.

15. Ramya Balaprabha G, Sai Mahitha Ch, Aparna K, Vikas Patnaik N, Shikha Singh, Abbulu K. Study of drug-drug interactions: a potential need for safe and effective usage of drugs in a teritary care hospital. IOSR J Pharm 2018;8:24-9.

16. Woron J, Lorkowska Zawicka B, Dobrowolska E, Serednicki W. Practical aspects of drug interactions in the pharmacotherapy in otolaryngology, or the seven cardinal sins of pharmacological treatment in otolaryngological practice. Otolaryngol Pol 2016;70:1-9.

17. Dais D, Cheruvathoor RA, RK, Rajagopal SS. Assessment of potential drug interactions among hospitalized patients in neurology department in teritary care hospitals. Asian J Pharm Clin Res 2019;15:173-6.

18. Ramalingam K, Rajagopal SS, Kandasamy K, Krishnan K. Assessment of potential drug interactions among hospitalized patients at the cardiac and pulmonology departments in teritary care hospitals. Asian J Pharm Clin Res 2018;1:443-9.

19. Koziolek M, Alcaro S, Augustijns P, Basit AW, Grimm M, Hens B, et al. The mechanisms of pharmacokinetic food-drug interactions-a perspective from the UNGAP group. Eur J Pharm Sci 2019;134:31-59.

20. India-consumption of alcoholic beverages 2016-2020 Statista. Available from: https://www.statista.com/ statistics/727026/ consumption-of-alcoholic-beverages-india. [Last accessed on 28 Feb 2020].
21. Texas MN, Indiana Jane Krause, Indiana Lulu Jin, Ohio Valerie Ng, Florida Mai Tran. Drug-alcohol interactions: a review of three therapeutic classes. Available from: https://www.uspharmacist.com.

22. Women's increased alcohol consumption contributing to India's growing love for alcohol: Survey | India News-Times of India; 2019.

23. Cheng C, Mithoowani F, Ungar T, Lee M. Interaction between psychotropic medications and alcohol: perceptions among patients attending an adult mental health day hospital program. Can J Hosp Pharm 2018;71:7-13.

24. Chandrupatla SG, Tavares M, Natto ZS. Tobacco use and effects of professional advice on smoking cessation among Youth in India. Asian Pac J Cancer Prev 2017;18:1861-7.

25. Kroon LA. Drug interactions with smoking. Am J Health Syst Pharm 2007;64:1917-21.

26. Bahekar S, Kale R, Varma S, Misra A. Drug-interaction-induced hemodynamically mediated acute renal failure in postsurgical patient. Med J DY Patil Univ 2014;7:359.

27. Drugs. com | Prescription Drug Information, Interactions and Side Effects; 2020.

28. Clinard F, Sgro C, Bardou M, Hillon P, Dumas M, Kreft Jais C, et al. Association between concomitant use of several systemic NSAIDs and an excess risk of adverse drug reaction. A case/non-case study from the french pharmacovigilance system database. Eur J Clin Pharmacol 2004;60:279-83.

29. Liu S, Yang L, Zhang L, Zhang X, He Y. The short-term efficacy and safety of methotrexate plus low dose prednisone in patients with rheumatoid arthritis. Zhonghua Nei Ke Za Zhi 2013;52:1018-22.

30. Drug Interactions results-MICROMEDEX; 2013.

31. Payne DA, Hayes PD, Jones CI, Belham P, Naylor AR, Goodall AH. Combined therapy with clopidogrel and aspirin significantly increases the bleeding time through a synergistic antiplatelet action. J Vasc Surg 2002;35:1204-9.

32. Drug Interactions results-MICROMEDEX; 2013.

33. Drug Interactions results-MICROMEDEX; 2013.

34. Broderick PJ, Benjamin AB, Dennis LW. Caffeine and psychiatric medication interactions: a review. J Okla State Med Assoc 2005;98:380-4.

35. Janchawee B, Owatranporn T, Mahatthanatrakul W, Chongsuvivatwong V. Clinical drug interactions in outpatients of a university hospital in Thailand. J Clin Pharm Ther 2005;30:583-90. 